\title{
Sentadas na estrela da salvação. Ser feminino em Ventos do Apocalipse, de Paulina Chiziane
}

\author{
Assunção de Maria Sousa e Silva*
}

\begin{abstract}
RESUMO
Este artigo tem como objetivo uma leitura acerca da condição feminina no romance Ventos do Apocalipse, de Paulina Chiziane, enfocando as personagens Minosse e Emelina, sua gênese, sua condição e efeitos de atitudes numa narrativa em que tradição e modernidade se entrelaçam. Para tal investigação, temos como suporte a ideia de transculturação de Ángel Rama e a poética da relação de Eduard Glissant. Quanto ao aspecto da condição feminina, apoiamo-nos nas ideias de Gayatri Spivak. Por essa via, ter-se-á a percepção de como as figuras femininas atravessam a narrativa desempenhando a função de estabelecer a relação entre a tradição e a modernidade, no quadro em que a condição é marcada profundamente pelo esfacelamento do ser em estado de guerra e sob o poder patriarcal. A análise se conduz com a perspectiva de visualização das formas humanizadoras que os sujeitos femininos reivindicam no enredo, cuja encenação se realiza no mosaico histórico de Moçambique. No romance, as personagens femininas atuam em posição e lugar de subalternidade similar à história da maioria das mulheres dos países pós-colonizados. Por fim, ao mesmo tempo em que elas internalizam a visão de aniquilamento, despertam uma consciência modificadora de si e dos grupos com os quais se relacionam. Minosse e Emelina são faces das que não se deixam vitimar apesar das forças que as querem aniquilar.
\end{abstract}

Palavras-chave: Condição feminina. Identidade. Relação. Identidade. Narrativa.

Às mulheres de minha terra.

\section{Introdução}

O romance Ventos do Apocalipse (1999), de Paulina Chiziane, narra os atos e efeitos de guerra nas aldeias moçambicanas: Mananga, Macuácua e Monte. Nesses espaços, as famílias e demais moradores - peregrinos atingidos pela guerra e,

* Professora Assistente UESPI/UFPI. Universidade Federal do Piaú - UFPI. Doutoranda em Literatura de Língua Portuguesa do Programa de Pós-graduação em Letras da Pontifícia Universidade Católica de Minas Gerais. Bolsista CAPES/FAPEPI. 
consequentemente, pela falta de comida e água -, usam das mais variadas medidas para sobreviver. A fome campeia e os homens têm ânsia de entender a causa para aplacá-la. Para isso procuram recorrer, conforme costumes e crenças, a rituais da tradição, por onde também se efetivam negociações e pactos entre os grupos étnicos existentes, a fim de dissipar a maldição e garantir a prosperidade da aldeia. Mas quando eles percebem que a tentativa de união não passa de um engodo, põem-se a peregrinar em busca de uma pretensa "terra prometida".

O romance é dividido em Prólogo, Parte I e II. No primeiro, três histórias míticas fundantes acolhidas das narrativas orais africanas, quais sejam "O marido cruel", "Mata que amanhã faremos outro" e "A ambição de Massuapai”, são apresentadas; a Parte I traz como epígrafe o provérbio "Nasceste tarde! Verás o que não vi." (CHIZIANE, 1999, p. 23) e a Parte II espelha-se na sentença "Cada dia tem a sua história." (CHIZIANE, 1999, p. 143).

Para contar a história, Paulina Chiziane cria uma narrativa estruturada por meio de entrançados fios temporais: passado, presente e futuro. As três narrativas orais introduzidas no Prólogo são motes, espelhamentos e, por que não dizer, gênese espaciotemporal da história do romance. O enredo se desenvolve por espaços dramáticos - Mananga, floresta e Monte -, nos quais os desvalidos, sujeitos em estado de esfacelamento moral, ético e social, conduzem-se desfalecidos.

As consequências da guerra provocam ciclos de tormentos cuja solução mais urgente é o êxodo. A peregrinação dos refugiados de Macuácua motiva-se pela procura de um lugar para sobreviver. A desterritorialização é tanto espacial quanto afetiva. Nas secas e tortuosas vias, floresta adentro, o narrador conduz-nos por um contar de gradativa sofreguidão, já que guerra, seca e fome não dão trégua.

$\mathrm{O}$ romance de Paulina Chiziane permite várias vias possíveis de análises. Uma delas seria investigar as causas, circunstâncias e os efeitos da guerra como elemento estrutural do enredo. Mesmo entendendo que este é tema gerador, não será neste artigo objeto de análise. Também não enveredaremos pelo exercício de perscrutar o desenvolvimento dos personagens Sianga e Sixpense que inicialmente dão dinamismo à história, como foco centralizador e impulsionador do narrado e das reflexões quanto à realidade e rumos do processo de dominação nas aldeias. Outro percurso de percepção seria destacar a forma como a guerra interfere sobremaneira nas relações intergrupais de mando masculino nos processos de desterritorialização em Ventos do Apocalipse. Propomos, porém, focar a condição feminina, situando a função narrativa de Minosse e Emelina, considerando-as elos de diálogo entre a tradição e a modernidade como também figuras representativas de identidades em construção como sujeito histórico e social no contexto pós-colonial. 
Gayatri Spivak, no ensaio "Quem reivindica alteridade?", situa o pensamento dos historiadores no contexto pós-colonial e, ao tratar dos "estudos subalternos", evidencia o feminino como sujeito complexo pelas configurações que são estabelecidas para ele, como a de ser incapaz de resolver estratégias em relação ao outro, enquanto sujeito imaginado no campo da literatura. Nessa perspectiva, a pesquisadora destaca a figura feminina subalterna, configurada como ser "colonial diaspórico [...] que negocia um espaço que pode não apenas historicamente, mas filosoficamente ser acessível a ela" (SPIVAK, 1994), a qual exemplifica com a condição da personagem Mary Oraon, de The hund, de Mahasweta Devi. Mesmo advertindo que tal configuração é a mais insidiosa, parece ser por ela que se pode perceber a estratégia de "falar de dentro", efetuando uma ruptura com o passado. Spivak nos convoca a perceber a "mecânica de fabricação da figura" e entender como a descrição do cotidiano orquestrado está legitimando as forças que vigoram no contexto pós-colonial. Consideramos, portanto, que, por essa via, pode-se compreender a presença e ação ficcional de Minosse e Emelina na obra supracitada, de Paulina Chiziane.

Das concepções de Angel Rama (1989, p. 32), interessa-nos a ideia referente à transculturação, quando o teórico recorre a Fernando Ortiz para argumentar que o termo é o que "melhor expressa as diferentes fases do processo transitivo de uma cultura a outra". Transculturação "não se limita apenas a aquisição de uma cultura, isto é, uma aculturação". O processo "implica também a perda de desenraizamento de uma cultura precedente, que se poderia chamar de desculturação e a consequente criação de novos fenômenos culturais que poderiam ser denominados de neoculturação " (ORTIZ apud RAMA,1989, p. 33-34). Para Rama, essa visão espelha a perspectiva latino-americana e revela resistência a considerar sua própria cultura, tradicional, que recebe o impacto externo e que tende a modificá-la, como uma entidade meramente passiva ou até mesmo inferior, destinada a maiores perdas, sem respostas criativas (RAMA, 1989, p. 33). Rejeitando a concepção de que a cultura tradicional se estabelece no processo, sob a égide da passividade, o teórico aponta a dupla comprovação: primeiro, a transculturação se compõe de valores idiossincráticos que operam atuando desde o passado; segundo, há uma certa energia criadora que a move, tornando-a diferente de uma simples agregação de padrões (RAMA, 1989, p. 34). Portanto, ele advoga que é pela capacidade de elaborar com originalidade, sobretudo em tempos difíceis, que a cultura tradicional demonstra pertencer a uma sociedade viva e criativa (RAMA, 1989, p. 32). Concebemos transculturação, portanto, como categoria que pode auxiliar na análise, e atentamos para os três níveis em que ela se processa, a saber: o da língua, da estrutura literária e da cosmovisão. 
No primeiro, o nível da língua, porque constatamos que em Ventos do Apocalipse, mesmo sob o estatuto do narrador em $3^{\mathrm{a}}$ pessoa, as personagens abarcam a "totalidade do texto, manifestando sua visão de mundo"; no segundo, a estrutura literária, porque explicita a "recuperação das estruturas de narração oral e popular", junto à conjugação do "verossímil e o histórico com a perspectiva maravilhosa pela qual o real é visto pelas personagens populares" e a forma como um discurso oralizado resiste semeando todo o romance. Por último, a cosmovisão, pelo engendramento de novos valores e novas ideologias, a partir das narrativas do Prólogo, fundadas nas crenças e, ao mesmo tempo, na propagação do mito.

As ideias de Édouard Glissant auxiliam na reflexão sobre a relação do eu/outro que bem se expressam na dinâmica das personagens Minosse e Emelina e o grupo, e no desvendamento das estratégias discursivas do narrado na sua "visão profética do passado", no processo de inserção da imprevisibilidade em relação à construção do mundo imaginado. Paulina Chiziane constrói a narrativa intercambiando presente e passado e assinala o futuro como um círculo de repetições que cada vez se renova, conforme as forças culturais do tempo.

\section{Ventos do Apocalipse - Estado de guerra e supressão da subjetividade feminina}

O universo narrativo, "manto negro que se destapa", decorre da intervenção de duas figuras masculinas importantes nas duas partes do enredo. Na primeira, há Sianga, régulo que dirige a aldeia Mananga, com poderes de dialogar com defuntos e fazer-lhes oferendas para aplacar suas fúrias. Com inicial destaque, Sianga, mesmo com seu poder centralizador, concebido e ungido pela tradição, não se distingue dos outros personagens vitimados pela guerra, como eles é igualado a animais ou até mesmo inferior a estes:

Que felizes são as cabras roendo pedras nos montes. Os ratos mastigam qualquer coisa em qualquer lugar e vão engordando à custa do nosso sofrimento, por que é que não roem também a desgraça da gente? O rato é senhor, agora, como pode ser ele superior aos homens, minha gente? É por isso que digo que Deus não é bom. Ah, mas se eu fosse Deus, todos saberiam o que é vida! (CHIZIANE, 1999, p. 28). 
Sianga, enquanto chefe da aldeia, faz negociações e drásticas concessões aos grupos rivais, cuja consequência é o subjugamento de seu povo às forças e aos grupos externos da aldeia. Entre uma estratégia e outra para se manter no posto de chefe, faz com que a população acredite que a falta de chuva é um castigo supremo cuja única saída é o ritual Mbelele ${ }^{1}$. Assim, induz todos, principalmente as mulheres, a realizarem o ritual, na tentativa de alcançarem em melhores condições de vida com a chuva que virá. No entanto, conforme podemos perceber, outras eram as causas de terríveis maldições em decorrência das decisões políticas e o processo histórico local. Isso se identifica nas cenas de negociações, traições, emboscadas, negligências do chefe Sianga e a falta de firmeza de seu grupo diante dos cavaleiros de fogo, uma rica alegoria do estado de guerrilha.

Na segunda parte do romance, destaca-se a figura de Sixpense, de Macuácua, protótipo de um guerrilheiro ativo, humano, humilde, consciente das forças em embate, capaz de resistir às intempéries com seus companheiros por caminhos e pragas das mais inóspitas durante o êxodo. Sixpense é severo, racional, porém complacente, afetivo e com determinação consegue levar o grupo até Aldeia do Monte. A terra prometida que inicialmente parece ser apenas mais um lugar de homens e mulheres desterritorializados, desesperançosos, torna-se o do encontro e da acolhida.

O trecho abaixo ilustra o momento em que Sixpense e seus companheiros chegam à Aldeia do Monte:

São os viajantes involuntários, ó gente, gritam uns para os outros enquanto abandonam os esconderijos. Correm em auxílio dos recémchegados, alguns deles foram também viajantes involuntários. A aldeia inteira recebe-os e dá-lhes as boas-vindas. Por fraternidade. Por solidariedade. Por compaixão. Por curiosidade. Por recordação dos momentos atrozes que passaram. Deus sabe quando e como. Uns alargam os olhos de esperanças de descobrir entre os recémchegados os familiares desaparecidos no último ataque à aldeia natal. Outros esperavam ver de entre os homens o filho que partiu para o combate há mais de três anos e jamais regressou. Outros não esperam nada nem ninguém, simplesmente assistem ao dilema. Choram. Choram por si e por tudo aquilo que foi vida, por que hoje já nada são senão detritos a que ontem tiveram orgulho de chamar vida. (CHIZIANE, 1999, p.185-6).

1 Mbelele é uma grande cerimônia, em que as mulheres desempenham o papel mais importante. Os reis e os eleitos conversam com os deuses da chuva. Dizem que é uma cerimônia difícil, porque para ser bem-sucedida deve correr sangue virgem. Escolhe-se entre a população um "galo que ainda não tenha sonhos de desejo e uma galinha que ainda não conhece a lua” (CHIZIANE, 1999, p. 59). 
Por esses personagens masculinos, Sianga e Sixpense, podemos compreender as relações sociais e de poder demarcadas na comunidade. Ambos, paradoxalmente, empreendem saídas do estado de reificação em que todos estão incluídos, porém não lhes é permitido, por força maior e secular, exercer a capacidade de efetivamente realizar mudanças consideráveis para a melhora nas condições de vida.

Essa imobilidade vivencial paralisante do masculino nesse cenário de guerra suscita atuações das figuras femininas que de toda forma são triplamente oprimidas. É válido, pois, indagar: qual é o lugar e posição do feminino nesse cenário de guerra? Para tentar responder tal pergunta, devemos considerar a estrutura da obra e as estratégias de construção do processo narrativo. Essas figuras femininas inicialmente marcadas por mudez, instaladas no solo dos sem voz, requerem de si um duplo esforço para fazer valer voz e ação, desejos e vontades em relação a si e, mais precisamente, à aldeia.

\section{As heranças narrativas no solo moçambicano e o lugar do feminino na relação tradição e modernidade em Ventos do Apocalipse}

O estudioso da tradição oral moçambicana Lourenço do Rosário ressalta que, para compreendermos o exercício da escrita nos países africanos, é importante atentarmos para a expressão da tradição oral, já que a escrita, no dado momento de investigação, só expressa o sentido de moçambicanidade à medida que os autores tomam para si a positiva dimensão da realidade da tradição. Além disso,

há a considerar que a compreensão do comportamento social das comunidades que, no seu conjunto, constituem o povo moçambicano, perante a conjuntura política actual, passa necessariamente pelo estudo prioritário daquilo que constitui o património predominante; a oralidade e seus valores subsequentes. (ROSÁRIO, 1989, p. 8).

Essa advertência é apropriada para o pacto de leitura do romance de Paulina Chiziane. A autora retoma as narrativas tradicionais moçambicanas com um propósito singular de valorizar o que há de mais genuíno no contexto cultural da nação mas, ao mesmo tempo, questionar a realidade presente, estratificada na tradição.

De certo modo, o acolhimento das narrativas fundantes contidas no Prólogo do romance, inicia um argumento discursivo arrojado no diálogo com a tradição. As 
histórias da tradição oral servem como espelhamento do quadro de guerra em que confluem os dois tempos, passado e presente, como forças propulsoras da narrativa. As histórias fundantes parecem nortear e, ao mesmo tempo, modelar o estar no mundo dos personagens e das comunidades étnicas, ao serem confrontados "com a situação política de mudança e renovação de parâmetros ideológicos" (ROSÁRIO, 1989, p. 9).

Observando os critérios estabelecidos por Rosário no estudo sobre os contos, lendas e mitos africanos, é interessante levarmos em conta aqueles critérios do ponto de vista morfológico, a fim de situarmos a narrativa de Chiziane. Rosário atesta:

Ainda dentro da linha morfológica e derivadas das duas primeiras [...], teremos: as narrativas cíclicas, quando a situação final repõe a situação inicial sem modificações qualitativas; "espiral, quando a reposição da situação inicial é efectuada a um plano qualitativamente diferente embora aparentemente semelhante"; em espelho, quando existe, na mesma narrativa, a possibilidade de conceder, conforme os actos praticados por cada personagem (num mínimo de duas personagens) que tiveram as mesmas oportunidades, um prémio ou um castigo; em cruzamento, quando o herói se defronta com, um falso herói, quer directa, quer indirectamente e o prémio daquele resulta do castigo deste e vice-versa; finalmente, teremos as narrativas de estrutura complexa, quando as diversas formas anteriormente mencionadas se articulam numa mesma narração. Este último caso depende muito do talento do narrador e pode-se afirmar que é a forma que mais próxima se encontra da escrita. (ROSÁRIO, 1989, p. 15 - destaque nosso).

Destacamos esse aspecto morfológico espiral das narrativas orais, por supormos haver similaridade quanto à estrutura do romance de Chiziane. O pano de fundo da narrativa, a peculiaridade espaciotemporal e a errância dos personagens contêm em si características geo-humanas similares às narrativas fundantes. As personagens estão submetidas às mesmas forças opressoras e excludentes, buscando como saída do quadro opressor similares atos de resistência e de afirmação de suas subjetividades, especialmente as figuras femininas. Minosse e Emelina vão projetar novas e distintas formas de intervenção no cenário narrativo, dando à trama uma dinâmica densidade e, ao mesmo tempo, compondo uma feição ao romance de viés questionador das ações políticas do atual contexto moçambicano.

O papel de Sianga assemelha-se ao de Sixpense, enquanto função de líder de uma aldeia com devidas responsabilidades, mas guarda, portanto, importantes 
diferenças no que tange à moral e à ética. Enquanto o primeiro sucumbe por rasurar o estatuto da tradição, o segundo encarna de forma altiva, porém tensa, a função de líder a comandar seu grupo até o Monte. O fio que conduz a história dos habitantes de Mananga, de Macuácua e de Monte é tal qual o dos seres despossuídos e sem perspectivas soantes nas histórias do Prólogo, realizando um movimento para trás tensionado com o embate/combate no reino de Muzila, com as histórias das mulheres do exército de Muzila e, especificamente, com a história de Massupai.

\section{Histórias fundantes}

São três as histórias-prólogo, fundantes de Ventos do Apocalipse: "O marido cruel" enreda a mudança de vida de um casal feliz no tempo de guerra. Com a escassez, o homem sai para o campo a procura de alimento, porém sacia-se sozinho chegando a casa com as mãos vazias. A mulher desconfia, segue-o e descobre-o sugando mel. E, em plena festa, desmascara-o e o abandona, levando os filhos consigo.

"Mata, que amanhã faremos outro" conta a história do tempo do Império de Gaza. Há muito tempo nas terras de Mananga, o reino foi invadido por outra tribo. O exército de Muzila saiu vitorioso e de levante a levante ia incorporando todos os jovens das terras a seu exército. Homens, mulheres e crianças fugiam do perigo desse exército e a norma era não fazer nenhum tipo de barulho, caso contrário a vingança era implacável. Se algum menino chorasse, todos seriam descobertos, no que o marido cochichava no ouvido da mulher: "Mata este que depois faremos outro"(CHIZIANE, 1999, p. 19). Depois o menino morto era escondido na mata, sem tempo para ser enterrado. O marido abraçava a mulher e consolava-a com a promessa de que fariam outro filho.

A história "A ambição de Massupai" inicia com a seguinte frase: "Em todas as guerras do mundo nunca houve arma mais fulminante que a mulher, mas é aos homens que cabem as honras de generais." (CHIZIANE, 1999, p. 20). Também a história se passa no velho Império de Gaza. Massupai era uma mulher muito bonita, mais que as cativas e as nobres ngunis esposas dos guerreiros. Os homens a saudavam ajoelhados, mas ela só queria o general. Este, morrendo de amores, transcendeu os limites e a proclamou rainha, desprezando as outras doze nobres esposas. Ambiciosa pelo lugar de única, Massupai pede a Maxalela - o valente guerreiro - que deixe as outras por ela. Este recusa a proposta, justificando que tinha uma posição de destaque, e propõe que, tendo mais terra e um maior reino 
que Muzila, dominaria todas as tribos e depois poderia abandonar suas mulheres. Ele, assim, seria rei de todos os reis e ela mãe de todas as mães. Para isso, porém, Massupai teria que matar os filhos dela e ajudá-lo a aniquilar os chopes.

Os chopes era gente da tribo de Massupai que Maxalela pretendia dominar. Ela aceita a proposta, regressa a sua aldeia, vende sua beleza aos guerreiros chopes e a guerra acontece. As esposas, sabendo do ocorrido, vão a Muzila e alertam-no sobre o plano do general. Muzila manda matar o general e jogar o corpo no relento para ser comido pelos cães. Quanto à Massupai, por ter prestado grande tributo ao Império de Muzila, não a mata, mas joga-lhe uma maldição de que ela seria abandonada e sempre a vaguear. Massupai enlouquece e tenta revolver os filhos das sepulturas com as mãos, foge para o mar e nunca mais é vista, apenas "seu fantasma deambula pela praia nas noites de luar, e quando as ondas furiosas batem sobre as rochas, ainda se ouvem os gritos: sou a rainha! Sou mãe desde o Save até ao Limpopo!" (CHIZIANE, 1999, p. 22).

As narrativas orais de uma dada cultura servem-nos como registro daquilo que dá sobrevida aos costumes e valores de uma comunidade e por elas podemos refletir sobre as configurações que se delinearam a posteriori para bem pensar o futuro. Para Rosário,

A narrativa oral é, e já tivemos ocasião de o afirmar por outras palavras, a mais importante forma de expressão da psicologia colectiva no quadro de toda a tradição oral de um povo. As várias categorias narrativas já referenciadas (contos, mitos, lendas, etc.) assim como os processos da sua transmissão, adaptação, contexto narrativo, os processos pessoais de contar (entoação, mímica) a recepção, reacção e projecção, podem determinar o índice intelectual da própria comunidade, bem como o grau de sedimentação de influências exteriores. Além disso, sabemos que a narrativa funciona como registro que documenta a sobrevivência de "usos, costumes, fórmulas jurídicas, valores morais e sociais" vigentes ou esquecidos pelo tempo. Aliás a ilogicidade que muitas vezes é patenteada por algumas sequências narrativas não passa de uma reminiscência de valores a nível do universo narrativo que há muito desapareceram da sociedade. (ROSÁRIO, 1989, p. 95 destaques nossos).

Um dos pontos que podemos evidenciar dessas histórias-prólogo no romance de Chiziane é a representação simbólica da figura feminina, elemento propulsor de choque e de desequilíbrio na ordem estabelecida. Com esta estratégia narrativa, podemos dizer que a escritora desempenha o papel próximo ao que Glissant designa 
ao intelectual e escritor na poética das relações. Para esse teórico, o intelectual e escritor contemporâneo, na dimensão do caos-mundo, traz uma "visão profética do passado". Essa visão consiste na busca ao passado que "não deve ser somente recomposto de maneira objetiva (ou mesmo subjetiva)" (GLISSANT, 2005, p. 102). Essa ficcionalização do passado que traz aquilo que por uma razão ou outra fora ocultado é indispensável para a compreensão de "Todo-o-mundo", que se situa no caráter "imprevisível da relação entre as culturas da humanidade de hoje". (GLISSANT, 2005, p. 105).

Pensando nessa imprevisibilidade da relação entre as culturas, os sujeitos em errância motivada pelo sofrimento, no romance de Chiziane, representam indivíduos desterritorializados ${ }^{2}$ no caos-mundo ${ }^{3}$. Nesse sentido, entendemos que a escritora aciona o que Glissant denomina de poética das relações em que o "Todo-o-mundo" dimensiona o caráter de identidade dos sujeitos. Isso se dá não mais pela reafirmação de um pensamento hegemônico e cristalizante, mas pelas contradições e aproximações deserarquizante entre opostos "nos espaços-tempos que as comunidades segregam em torno de si” (GLISSANT, 2005, p. 102).

No processo de narrar os caminhos, ou melhor, descaminhos dos personagens, o narrador empreende um discurso de desmascaramento, expondo os conflitos, as contradições, as negações ao outro no espaço de embate que compõem o ambiente de guerra.

É ilustrativo o episódio do Mbelele, já mencionado anteriormente. Se, por um lado, há a necessidade da realização do Mbelele, como retomada dos costumes e das tradições para salvar o povo da maldição e da fome, já que os deuses abandonaram a terra, segundo os chefes da aldeia, por outro, é vergonhoso para as mulheres recorrerem àquele ritual já que lhes causa constrangimento e indignidade (capítulo 4 da I parte), quando são seus corpos nus que estão manipulados: "Desgraça, desgraça, só desgraça. (...) O mbelele? Que vergonha! Mulheres nuas com traseiro de melancia a exibir as mamas aos pássaros e o cu aos gafanhotos faz chover? Que vergonha!" (CHIZIANE, 1999, p. 58).

Enquanto isso, o narrador evidencia choques e alterações dos costumes e das tradições sofridos e decorridos do fenômeno da migração dos filhos da terra que, consequentemente, abandonaram os deuses e, ao voltar, chegaram descrentes das tradições e com diferentes visões sobre a cultura que ali deixaram:

2 Desterritorializado, conforme Deleuze e Guattari, é aquele que sai de seu "território" em busca de um outro, no processo de naturalmente reterritorializar-se. (Cf. DELEUZE; GUATTARI, 2009).

3 Caos-mundo, segundo Glissant, é "o choque, o entrelaçamento, as repulsões, as atrações, as conivências, as oposições, os conflitos entre as culturas dos povos na totalidade-mundo contemporânea. [...] trata-se da mistura cultural [...] condição temporal da cultura, da relação entre as culturas. (GLISSANT, 2005, p. 98). 
Os costumes e as tradições sofreram alterações nos últimos séculos. As gentes ouviram as palavras dos homens vindos do mar e transformaram-se; abandonaram os seus deuses e acreditaram em deuses estrangeiros. Os filhos da terra abandonaram a tribo, emigraram para terras estrangeiras e quando voltaram já não acreditavam nos antepassados, afirmaram-se deuses eles próprios. (CHIZIANE, 1999, p. 60).

A imprevisibilidade do sistema desloca a possível ordem. Esse efeito nos leva a retomar o teórico antilhano, na sua reflexão quando ao papel do literário no "imaginário do Todo-o-mundo":

Faz-se necessário captar a medida-desmedida da visão profética do passado e do imaginário da Relação acrescida do tratamento dos rastros/resíduos das condições iniciais, da imprevisibilidade e deste novo tecido que precisa ser criado, que não corresponde mais ao reflexo da essência mas à rede das relações, da relação com o outro e das relações com as outras culturas. O Todo-o-mundo é uma desmedida. (GLISSANT, 2005, p. 108-9).

No contexto de guerra Ventos do Apocalipse, as personagens femininas, Emelina e Minosse, têm função de atuar como sujeitos problematizadores ou/e modificadores no campo de força desse "caos-mundo". Elas se apresentam como elos, numa dimensão identitária com o outro: ora (Emelina) corroborando para a acentuação do estado de subjugamento e fortificação do poder político, sempre movida menos por uma consciência da realidade sociopolítica e mais pelo sentimento dos afetos por homens com posição de poder; ora (Minosse) representando a resistência no mundo de desgraça e fome a vislumbrar o valor maior de humanização nas relações interpessoais e sociais.

\section{Personagens femininas como destaque no contexto de guerra}

Em Ventos do Apocalipse, os personagens, sempre em errância, buscam a terra melhorada e próspera, consciente ou inconscientemente, como forma de atender a necessidade da sobrevivência. A peregrinação lhes reserva o que há de mais perverso mas também o que há de compensador nas relações interpessoais. Relações que espelham ambiguidades e reservas entre dominador $x$ dominado. Nesse contexto, as personagens femininas sofrem dupla subjugação. 
Enquanto as personagens masculinas são vitimadas pelas relações de poder político e mítico, as femininas são alvo dessas relações de poder mítico, político, além do patriarcal. Elas estão inicialmente à deriva, projetadas em suas fragilidades e subestimação masculina, circunscritas na visão patriarcal de que a mulher é um mal para a humanidade. O que acontece de ruim é fruto de atos ou omissões das mulheres - máxima recorrente ao longo da narrativa. As figuras femininas são movidas por forte sentimento instintivo e irracional de transgressão e violação da natureza, conforme vigora no mito judaico-cristão e demais narrativas míticas por ele influenciadas. Assim se assenta a condição feminina, sua gênese, sua construção e sua sustentação, que é questionada no romance de Paulina Chiziane.

Vejamos a passagem do enredo em que todos estão reunidos para julgar os que violaram a lei, durante o ritual do Mbelele, cujo alvo central da culpa são as mulheres:

O tribunal estreou-se com o julgamento das mulheres. Quer as velhas quer as jovens sofreram um julgamento dramático. Havia argumentos de sobra: a mulher é a causa de todos os males do mundo; é do seu ventre que nascem os feiticeiros, as prostitutas. É por elas que os homens perdem a razão. É o sangue impuro por elas espalhado que faz fugir as nuvens aumentando a fúria do Sol. Os juízes instigados pelos homens do Sianga flagelam impiedosos as mulheres desprotegidas. (CHIZIANE, 1999, p. 92).

Como vimos na seção anterior, as narrativas recontadas no prólogo do romance já nos apontavam o lugar feminino na tradição moçambicana. Lá se destacam posturas e modos que delineiam os perfis dispostos à mulher na cultura: a de mãe - natureza provedora e protetora de seus filhos, que não aceita viver sob o jugo do marido cruel, na primeira história; a de mulher frágil que não tem perspectiva ou força diante do dominador e mata seus filhos, como na segunda; e de mulher perigosa, traiçoeira, desvairada de amor, que abala a harmonia de sua aldeia em razão de sua ambição amorosa, cooptada pela ambição de poder do amante, na terceira. São perfis e representações que muito se aproximam das figuras emblemáticas do enredo: Emelina e Minosse.

Emelina e Minosse são antíteses, mas ambas retratam os sujeitos de dignidade sonegada e identidade fraturada. Emelina - a louca - desencarnada da história de Massuapai, em errância e marginalizada, desterrada pelos seus próprios companheiros, não é ouvida por eles, é isolada do grupo, excluída das decisões e banida dos parcos benefícios que os demais possuem; Minosse passa por um 
processo de construção de identidade progressiva. Na primeira parte do romance, em que impera o mando de Sianga, seu marido, ela não tem voz; como já assinalamos, internaliza suas mágoas, não participa efetivamente das decisões da comunidade, porém quando Sianga é descoberto como traidor, julgado e morto, deixando a aldeia estarrecida, Minosse toma consciência de si e destaca-se de forma comovente.

\section{As personagens nas relações de poder e em (des)construção identitária}

\section{Minosse}

Minosse é a personagem presente nos momentos cruciais da narrativa. Há, entretanto, explícita modificação em sua identidade. No primeiro espaço em Mananga, aparece como uma das esposas de Sianga, mulher lobolada, subjugada pelo pai e depois submetida aos caprichos e interesses do marido para manutenção deste como chefe da tribo. Mantém-se calada nos momentos de maiores infortúnios: no disfarçado interesse do marido pela filha, na apreensão que sente pelo destino da filha, na morte dos filhos e neto, na obrigação de ter que fazer prolongar as migalhas de alimento do dia a dia e na indução do marido para que vendesse seu corpo em troca de alimento.

Em Mangana, Minosse representa o ser gravemente vitimado pela arrogância do poder masculino e, por conseguinte, encontra-se em maior grau de subalternidade. Todavia, no momento de necessidade de fuga e peregrinação por caminhos ermos e incertos, sem perspectivas, a personagem entra num processo de transformação e construção de sua identidade. E, como sujeito consciente da dupla exclusão, passa a representar a voz de resistência da tradição em meio à corrosão e ao malefício que a guerra proporciona. Minosse se põe na vanguarda do grupo na floresta, "abrindo novos caminhos" mata adentro e os outros a acompanham.

A voz de Minosse se confunde com a voz do narrador no fluxo da narrativa. Como na passagem em que ela começa a expressar-se consciente da submissão de homens e mulheres na tirania dos espíritos. Ao indagar, descobre o que estava ocultado para si e para o grupo no atordoamento que a vitimação provoca: 
Minosse sente uma solidão absoluta. Cheia de desespero recobra a força interior e grita, a dor ultrapassa os limites toleráveis:

- Deus do Céu e da Terra, espírito dos Mathe e dos Mausse, por que me abandonaram?

Rasga as vestes, fere o corpo, esgaravata a terra e cai inconsciente.

- Mas porquê tanta desgraça, filhos de Mananga, filhos de Deus e dos defuntos, porquê tanta desgraça?

Os espíritos revoltam-se, porque no mbelele, o chefe comeu a parte dos defuntos. As corujas cantaram à meia-noite. $\mathrm{O}$ gato preto atravessou o caminho na sexta-feira. Um pai dormiu com a filha. Um filho matou a mãe.

O fogo no ar.

$\mathrm{O}$ rio de sangue.

Sangue do ovo e do filho do homem.

Sangue vermelho manchando o Sol!

(CHIZIANE, 1999, p. 141).

À medida que avança pela mata, rumo à aldeia do Monte, o grupo desperta para o sentido da inútil guerra e suas consequências. Sob comando de Sixpense, guerrilheiro que trabalhou nas minas do Rand e lutou na guerrilha da Independência, a comunidade questiona os motivos da guerra, discute com clareza sobre o sentido da liderança, confronta os preceitos da tradição com os indícios da modernidade nos caminhos em ziguezague:

A viagem para o Monte é feita aos zigue-zagues com o coração permanente sobressalto, cada dia tem uma história e cada noite novas emoções. A noção do espaço e do tempo dilui-se nas trevas, perdeu-se o sentido da distância. (CHIZIANE, 1999, p. 165).

Predomina, nessa parte da narrativa, a voz do narrador intercalada às dos personagens como alguém que se introjeta no meio e assume participar das discussões. No percurso em ziguezagues, afloram novas possibilidades de convívio entre os peregrinos e destes com a natureza em semelhante estado e condição de sofrimento e "morte na batalha do alimento".

É nessas paragens que Minosse "dá um mergulho fundo no oceano celeste sem se dignar dar uma palavra que testemunhe a sua percepção do mundo dos vivos" (CHIZIANE, 1999, p. 208). Ao chegarem à terra esperada, no encontro com os outros, em Monte, os de Mangana se dão conta de que a guerra não minou apenas as possibilidades materiais, mas também as de afeto. A lição vem quando 
eles são recebidos pelos moradores de Monte, cuja situação é a mesma, mas estes não demonstram dureza no coração. Os de Monte os saúdam e lhes dão boas vindas, os peregrinos ficam perturbados: "Foram recebidos conforme a lei da tribo e respeitados segundo a tradição. [...] Os de Mananga não cabem de si de tanta surpresa. Sentem remorsos das atitudes passadas" (CHIZIANE, 1999, p. 189).

Outro episódio é mais forte para Minosse modificar aquela realidade. A presença do menino traquino e malvado, banido do grupo, que vive às margens dos acontecimentos provoca na personagem a lembrança do filho Dambuza e com isso seu sentimento maternal de proteção, amparo e de pertença aflora. Minosse compara a realidade dos refugiados diante do grupo opressor com a atitude interna do grupo para com o menino abandonado e vê a desagregação moral e humana do grupo. Do restrito e individual ato ao clareamento dos rasgos da realidade coletiva:

Minosse olha para o menino encharcado tremendo de frio e sente um nó na garganta. É tudo estupidez - pensa. Porque na panela não há comida, todos temem abrigar mais um estomago e inventam as fantasias mais absurdas deste mundo. Loucos. (CHIZIANE, 1999, p. 220).

Pela voz de Minosse, clama a voz da consciência do grupo desvalido. O menino é um ser "desiludido, e destruído, alma virgem de inocência perdida" (CHIZIANE, 1999, p. 221). A voz de Minosse ressoa a voz do narrador, ou melhor, o narrador imprime em sua voz a de Minosse e, através do discurso indireto, indica o sujeito em ação despertada: "Vamos, levanta-te, vem comigo" (CHIZIANE, 1999, p. 221). A partir daí, Minosse parece ser outro sujeito renovado: "Sente de novo alegria de viver. Aproxima-se de toda gente, conhece novos rostos, faz novas amizades porque quer construir uma nova família" (CHIZIANE, 1999, p. 224).

Reconstrói-se gradativamente a subjetividade no exercício da alteridade que vai se consolidando em novas adoções. $\mathrm{O}$ menino solidário estimula Minosse a lutar pela adoção da desvalida Sara. Ambos têm histórias parecidas: família de mortos, abandonados que vagam na aldeia. A adoção dessas crianças por Minosse, mais do que expressão de sentimento materno, conota a dimensão do ser feminino de acreditar na possibilidade de mudança de mentalidade da sua aldeia, pois é preciso acreditar no outro para agregar novas formas de estar no mundo: 
orientados por ela. Ensina-lhes as manhas da terra, os segredos da semente, as voltas da água e os movimentos do vento. Ela não pode ensinar mais que isso. Lamenta o facto de não haver na aldeia uma escola onde possam aprender outros modos de vida porque o mundo moderno tem exigências que ela desconhece. As crianças deliram porque a velha apagou neles o fogo do terror. Quando a noite chega, sentam-se à volta da lareira e contam histórias. Falam do futuro. A Sara diz que não quer ter nenhuma profissão, mas quer ser esposa e fazer filhos. O Mabebene diz que quando for grande quer ser presidente da república para acabar com todas as guerras do mundo. $\mathrm{O}$ mais pequeno o Joãozinho, quer ter um camião para meter os produtos da machamba e vender no mercado da vila. (CHIZIANE, 1999, p. 231-2).

Observando a forma como Minosse se posiciona na segunda parte da narrativa e relembrando as narrativas fundantes do prólogo do romance, percebemos o que há em comum entre Minosse e a da mulher-mãe na história "O marido cruel". Ambas fazem o mesmo movimento de tomada de consciência de sua realidade de exclusão e buscam um futuro promissor para seus filhos. Nesse sentido, podemos inferir que, do meio da guerra e em condição de subalternidade, a ação é primordial não só para questionar o poder hegemônico, mas, sobretudo, para materializar novos modos e rumos de pertencimento e inserção nas relações entre os indivíduos e entre as culturas.

\section{Emelina}

O ambiente se modifica em Monte. "Um manto negro cobre o céu da aldeia, a noite invade novamente os destinos dos homens" (CHIZIANE, 1999, p. 20). Tal descrição da paisagem enuncia a presença de Emelina, uma personagem antítese de Minosse, já dito, que circunda às margens do grupo e da aldeia de forma fantasmagórica.

Emelina encarna ambiguidade. Se, na primeira parte do romance, passa despercebida, confinada a lugares afastados, solitária, coberta de silenciamentos, assombros e mistérios, na segunda parte, a personagem se traveste como ser ambíguo, antagônico, agindo "na noite" e provocando sustos. À primeira vista, não passa de um ser esquisito para todos, com o qual não se deve mexer nem se importar, no entanto cresce e incomoda como ser destrutivo do espaço e do tempo que os habitantes persistem em construir. 
A miséria em toda parte, diarreia, desnutrição, escassez de alimento, falta de remédio são condições que justificam a assistência social enviada pela Europa, América, Ásia e Austrália, mas Emelina hesita em aceitar. O corpo de Emelina é o corpo do sacrifício. A voz de Emelina é a não-voz, a que se nega a aceitar as benesses do estrangeiro que não passam de medidas assistencialistas, sob outra ordem, em nome do apaziguamento da miséria e da fome. A negação de Emelina ressoa como um ponto de vista que se firma por dizer que não seria com aquelas medidas que se alcançaria a paz e a justiça em Monte.

Os mais velhos também desconfiam da ajuda, pois se lembram da colonização e tentam convencer os mais jovens a não aceitá-la, porém a crítica situação os faz passar novamente "pela humilhação da esmola". "Os velhos sentem que a outra face da ajuda é um mistério maldito que trará aos homens novas amarguras na hora da descoberta" (CHIZIANE, 1999, p. 235). O narrador nos aponta o jogo, o risco de uma nova colonização mental. O trecho abaixo evidencia os sentidos despertados pela ajuda internacional que chegara:

Quando esta comida acabar, receberemos outra. O povo não exerce os seus deveres, as suas tradições, e espera pela esmola, nova forma de colonização mental. Mas nem tudo o que vive no mar é peixe. A desgraça de uns é a sorte dos outros. Alguns indivíduos neste grupo com o pretexto de ajudar, ajudam-se. (CHIZIANE, 1999, p. 238).

A ironia demarcada neste trecho a seguir alerta para a denúncia da colonização mental acima referida:

Os filantropos, do seu pedestal, dão a mão desinteressada. As vítimas do abismo, de joelho recebem o auxílio de mão erguida no ar. Como na prece. Deliram, satisfeitos, porque recebem o maná vindo da misericórdia divina, Deus ouviu os nossos lamentos. (CHIZIANE, 1999, p. 238).

A atuação de Emelina cresce sobretudo nas cenas da assistência estrangeira aos desvalidos de Monte. Sua história é como "uma história igual a de todos os tempos, karingana wa karingana" (CHIZIANE, 1999, p. 247). O que difere, todavia, é sua posição como sujeito que fala, aquela voz subalterna capaz de romper o silêncio e fazer-se ouvir. Emelina traz a lucidez do ser feminino que sempre esteve às margens e que tem no espaço da narrativa o seu momento para falar: 
- Sabe, enfermeira, todos nós nascemos com uma estrela emigrante. Quando está na testa nós brilhamos e tornamo-nos vistosos, famosos. Quando emigra para o peito ficamos altruístas e todo mundo nos rodeia. Outras vezes a estrela emigrante percorre a linha divisória das nádegas, entala-se no cu e sentamo-nos sobre ela. Essa é a situação em que me encontro agora. Estou sentada sobre a estrela da minha salvação. (CHIZIANE, 1999, p. 248).

A história dessa personagem tem o percurso de uma estrela cadente. Profundamente filosófica, como enfatiza o próprio narrador, o discurso de Emelina surpreende Danila, que a escuta em sua autoidentificação. Emelina não responde a nenhuma forma de olhar piedoso, não corresponde à ótica do amor universal. Ao contrário, reforça a imagem de "parceira da serpente", maldosa, capaz de matar os filhos por amor ao amante estrangeiro afamado por seduzir as mulheres e todos da aldeia.

O homem, "líder poderoso" que tinha muitos "homens reles obedecendo às suas ordens" (CHIZIANE, 1999, p. 249), induz Emelina a matar os filhos que ela tivera com o marido, pois depois faria outros com ela. Emelina age por prazer e ambição: "ambiciosa exigia provas de amor cada vez mais impossível"; deixa extravasar suas vontades, quer o amante só para si e também o impõe a matar suas mulheres.

É, porém, com ironia na narrativa que o homem é chamado pela razão e decide abandoná-la. A dicotomia emoção/razão está bem marcada pelo jogo de dominação entre o duplo feminino/masculino. E nesse jogo Emelina parece condenada ao baixo, ao expurgo. "Quando viu seu castelo afundado, Emelina começou a percorrer os caminhos, desorientada. O homem desaparecido levoulhe a alma com ele, não se recupera mais Emelina" (CHIZIANE, 1999, p. 251). Para o narrador, "a história que Emelina conta à enfermeira na esperança de ser compreendida" é entendida apenas uma parte, visto que a "gente da cidade tem outra visão do mundo" (CHIZIANE, 1999, p. 251), e deixa a nós, leitores, a pergunta: estamos compreendendo a complexidade dessas esferas dicotômicas na constituição do narrado?

Essa é a deixa para tentarmos entender a estratégia discursiva de Paulina Chiziane e tecermos algumas inferências. A primeira, a história contada alerta quanto à circularidade das histórias de todos os tempos karingana wa karingana. A história de Emelina decorre sob o estrato da história d' "A maldição de Massupai". Há na trama similar concepção, contudo tons discursivos e projeções de apelo social marcam a diferença; a segunda, a história de Emelina circunda-se 
no contexto da modernidade que indicia os efeitos das pegadas do colonizador. A figura do amante é paradigma daquele que tem poder, poder não só sobre suas mulheres, mas sobre as decisões políticas da comunidade. É a história que revigora os tempos do Império de Gaza sob a dominação colonial mas também os seus desdobramentos, em que a mulher é duplamente subjugada e elemento manipulado para a manutenção do poder masculino.

A aparição de Emelina na grande festa final de Ventos do Apocalipse tem um significado e clamor político. Emelina representa o signo da maldade e o espírito de contravenção que envolve o todo da aldeia, aquilo que todos gostariam de negar, que atordoa e que provoca ruptura entre o preestabelecido, o que foi e o que poderá vir a ser:

Lamenta-se, murmura-se e conclui-se: ela é desmiolada, é estranha, esquisita, é melhor deixá-la no seu mundo. De resto só viria manchar o ambiente. Está esfarrapada e malcheirosa, não se lava desde que chegou ao monte há mais de dez meses, deixai-a em paz, não faz falta aqui. [...] A sorte dela reside na loucura porque se assim não fosse, seria bem controlada e (sic) obedecer aos princípios de segurança e vigilância do povo do Monte. Nós aqui construímos a paz e não permitimos comportamentos estranhos. Mas há qualquer coisa de misterioso nos movimentos de Emelina [...] (CHIZIANE, 1999, p. 270-71).

Emelina, louca, incomoda e abala a efêmera "paz" conquistada em Monte. Todos estão absortos, extasiados com a pose do padre que reza a missa, ritual entre outros rituais que ali se celebram. "Um vendaval surge inesperadamente e cobre o céu" (CHIZIANE, 1999, p. 273). Misturam-se rituais religiosos, a chuva cai, o silêncio. Nessa atmosfera, irrompe a figura andrajosa de Emelina que ri, projetada no alto. A violência do riso tem a capacidade de desintegrá-la e desorienta a comunidade. Com essa imagem de Emelina, as possibilidades de paz e de um futuro próspero ficam sob suspense. "A confusão é total." (CHIZIANE, 1999, p. 274)). De onde vem tanta desgraça? A sentença do mal feminino perdura e fecha o enredo. "Foi ela quem conduziu a fogueira que incinerou a vida, acabando também queimando-se nela, foi ela e não outra e nós a pensarmos que era doida, ó gente" (CHIZIANE, 1999, p. 275). O fogo conduzido por Emelina torna-se o fogo de batismo da aldeia.

A alegoria dos cavaleiros de fogo semantiza o viés crítico da narrativa. A descida espetacular, hiperbólica, causa ofuscamento à vista de todos da aldeia. A 
cena causa vertigem. E os cavaleiros dominam o espaço para efetuar o batismo de fogo.

\section{Considerações finais}

Paulina Chiziane conquistou um lugar de destaque na literatura moçambicana. Sua obra reacende reflexões quanto ao papel do intelectual contemporâneo. Segundo a poética da relação de Glissant, o/a intelectual e escritor/a é o ser em relação com o mundo e com o cosmos que com sua imaginação se insere na imprevisibilidade. Não há, nessa perspectiva, lugar para as ideias absolutas afeitas à identidade de "raiz única", em que cada um se estabelece em campo e lugares estáticos. Nesse contexto, as pessoas estão sempre identificadas em relação com os outros, em errância, na prevalência do caos, onde predominam "as possibilidades de repetições e de contradições" (GLISSANT, 2005, p. 97). A narrativa de Ventos do Apocalipse traz, no bojo discursivo de vozes diversas e diferentes, a alusão à realidade pós-colonial moçambicana com seus específicos elementos sociopolíticos e culturais, sobressaindo, especialmente, a realidade do sujeito feminino.

O universo de conflitos que sinalizam para o centramento e o comando de dois sujeitos masculinos, Sianga e Sixpense, termina por desviar-se para ativa participação de Minosse e Emelina. A primeira percorre o caminho de construção de sua identidade, a partir do momento em que desperta sua consciência para a realidade de guerra e para sua relação com os mais marginalizados do grupo, no caso, as crianças; a segunda traz, em sua gênese, a maldição atribuída ao feminino e mantida pela tradição, através da visão mítico-patriarcal, mas é nela que a aldeia tenta ocultar aquilo que bem espelha a comunidade.

Ambas as personagens sofrem a opressão sistêmica em que a ordem é manter o sujeito feminino em silêncio, na inapetência e passividade, na condição de ser subalterno. A opressão, porém, parece ser uma força incapaz de deter o movimento que nasce desse sujeito feminino para modificar sua condição e seu espaço ou pelo menos problematizá-lo. Podemos dizer, pelo percurso das duas personagens, que a narrativa se distancia das concepções de um feminismo combativo e radical, na intervenção incisiva de adoção de novos paradigmas libertários. No entanto, é inquestionável a valorização da posição do feminino e de sua tomada de consciência no cenário de opressão, apesar de, mesmo conscientes, ainda estejam sentadas na estrela da salvação. 


\begin{abstract}
This article aims to be a reading of the condition of women in Paulina Chiziane's novel Ventos do apocalipse (1999), focusing on the characters Minosse and Emelina, its genesis, its condition and effects of actions in a narrative in which tradition and modernity intertwine. For this investigation, we use the idea of transculturation by Angel Rama, the poetics of relation by Édouard Glissant, and Gayatri Spivak's ideas of feminine condition. This theoretical course implies the possibility of understanding how these female figures cross the narrative as subjects whose function is to establish the relation between tradition and modernity, deeply marked by the disintegration of being female in a patriarchal society going through a state of war. This analysis considers the perspective of visualizing the humanizing forms claimed by the female characters, whose performance speaks to the history of Mozambique. We realize that, in the novel, the female characters represent the place of inferiority occupied by most women in post-colonized countries and their life stories.
\end{abstract}

Keywords: Feminine condition. Identity. Relation. Narrative.

Referências

CHIZIANE, Paulina. Ventos do Apocalipse. Lisboa: Editora Caminho, 1999.

DELEUZE, Gilles; GUATTARI, Félix. Mil platôs: capitalismo e esquizofrenia. Traducão de Aurélio Guerra Neto e Célia P. Costa. São Paulo: Editora 34, 2009. GLISSANT, Édouard. Introdução a uma poética da diversidade. Tradução de Enilce do Carmo Albergaria Rocha. Juiz de Fora: Editora UFJF, 2005.

RAMA, Angel. Transculturación narrativa em América Latina. Fundación Angel Rama. Montevideo: Arca Editorial S.R.L., 1982.

ROSÁRIO, Lourenço Joaquim da Costa. A narrativa africana de expressão oral: transcrita em português. Lisboa: Instituto de Cultura e Língua Portuguesa, 1989.

SPIVAK, Gayatri. Quem reivindicar alteridade? In: HOLLANDA, Heloisa Buarque de (Org.).Tendência e impasses: o feminismo como crítica da cultura. Rio de Janeiro: Rocco. 1994. p. 187-217. 
